\title{
Abstract Law and Political Reality in the Post-European-Accession British Constitution
}

\author{
7. W. Bridge*
}

"the tide is advancing. It is no use our trying to stop it, any more than King Canute did. He got his feet wet. I expect we shall all get our feet wet too."

Lord Denning ${ }^{1}$

\section{Introduction}

Just over fourteen years ago the United Kingdom acceded to the European Communities. Membership has necessarily involved accepting "the whole corpus of accumulated Community law, particularly in the decisions of the Court of Justice since 1952."2 Among those decisions, by far the most important and significant lay down the twin doctrines of the supremacy of Community law and the direct enforceability of Community law in the courts of the member states. ${ }^{3}$ At midnight on 31 December 1972/1 January 1973 we therefore entered a new constitutional world which is not an amorphous one but one which exists within a designed framework established by the Treaties. ${ }^{4}$ Our membership was initially subject to a period of transition, ${ }^{5}$ but after that had passed we became subject to the full scope and force of Community law. As the European Court put it: "The expiry of the transitional period laid down by the Treaty meant that, from that time, those matters and areas explicitly attributed to the Community came under Community jurisdiction." ${ }^{6}$ Whilst some still minimise the domestic impact of membership of the Community as little more than participation in a Europe des

*Professor of Public Law in the University of Exeter.

1. "The Incoming Tide (Inaugural Lord Fletcher Lecture, 10 December 1979), in The Lord Fletcher Lectures 1979-1982 (1983), 3 at p.4.

2. House of Lords, Select Committee on the European Communities, Session 1977-78, 17th Report, The Enlargement of the Community, Vol. 1, Annex A, para. 2.

3. See D. Lasok and J. W. Bridge, An Introduction to the Law and Institutions of the European Communities 3rd ed. (1982), pp. 116-153.

4. Cf. J. D. B. Mitchell, "Constitutional Law", in Then and Nom 1799-1974 (1974), 73 at p.100.

5. See Treaty and Act of Accession 1972, JO 1972, L73/4.

6. Case 231/78 E. C. Commission v. United Kingdom [1979] E.C.R. 1447 at p. 1461. 
patries, ${ }^{7}$ the general consensus of scholarly opinion is that the impact has clearly been constitutional, even if views differ over the sense in which that term should be employed. ${ }^{8}$ Within that consensus, with one major exception, ${ }^{9}$ runs a common theme that while the continuing nature of the sovereignty of the United Kingdom Parliament ${ }^{10}$ remains intact, a range of practical considerations permit us to honour the legal obligations of Community membership. This is borne out by the fact that over the past fourteen years, despite the apparently precarious and uncertain nature of our membership, ${ }^{11}$ we have very largely played the game according to Community rules. Our judges have not only applied Community law they have also acknowledged its supremacy, at least de jacto, ${ }^{12}$ and the eponym who graces this foumal has been credited with accomplishing a "dexterous revolution". ${ }^{13}$ Parliament, subject to one exception to be discussed later, has made no apparent attempt to legislate contrary to Community law. Further, when the Court of Justice has adjudged the law of the United Kingdom to be deficient in its implementation of Community objectives the necessary corrective action has been taken. ${ }^{14}$

It is the aim of this article to examine the apparent paradox that while the new European dimension of our law "has not yet upset the basic properties of the legal universe" 15 there have nevertheless been major and, it will be argued, enduring

7. See I. Harden and N. Lewis, The Noble Lie (1986), at p.310.

8. See, for example, P. Bromhead, Britain's Developing Constitution (1974) Ch.22; O. Hood Phillips, Constititional and Administrative Law 6th ed. (1978), at pp. 142, 146 and 222; J. Usher, Eumopean Community Law and National Law (1981); T. C. Hartley and J. A. G. Griffith, Govemment and Law 2nd ed. (1981), at pp. 403-407; L. Collins, European Community Law in the United Kingdom 3rd ed. (1984), at pp. 21-33; C. Turpin, British Government and the Constitution (1985), ch.5; S.A. de Smith, Constitutional and Administrative Lam 5th ed. (1985), at pp. 37-38, 90-94, 104, 108; E. C. S. Wade and A. W. Bradley, Constitutional and Administrative Law 10th ed. (1985), at pp. 81-82, 102-103, 135-138.

9. See the writings of J. D. B. Mitchell, in particular "What Happened to the Constitution on Ist January 1973?", (1980) 11 Cambrian Lam Review 69, who argued that by entering a new but established polity the British Constitution experienced a revolutionary change which varied its fundamental legal principles. On the possible transfer of sovereignty see J. Usher, European Community Lam and National Law (1981).

10. See H. W. R. Wade, "The Legal Basis of Sovereignty", [1955] Cambridge Lam 7oumal 172 and H. L. A. Hart, The Concept of Law (1961), at p.146. The writer subscribes to this view.

11. As suggested by Lord Bridge of Harwich, "Attempts towards a European Constitution in the light of the British legal system", in J. Schwarze and R. Bieber (Eds.) Eine Verfassung fur Europa (1984), at pp. 119-120.

12. For a review of the cases see D. N. Clarke and B. E. Sufrin, "Constitutional Conundrums: The Impact of the United Kingdom's Membership of the Communities on Constitutional Theory", in M. P. Furmston, R. Kerridge and B. E. Sufrin (Eds.) The Effect on English Domestic Law of Membership of the European Communities and of Ratification of the European Corvention on Human Rights (1983), 32 at p.57 et seq.

13. See T. R. S. Allan, "Parliamentary Sovereignty: Lord Denning's Dexterous Revolution", (1983) 31 Oxford Joumal of Legal Studies 22.

14. For example, the Passenger and Goods Vehicles (Recording Equipment) Regulations 1979, S. I. 1979, No. 1746 made in response to Case 128/78 E. C. Commission v. United Kingdom [1979] ECR 419, and the Equal Pay (Amendment) Regulations 1983, S. I. 1983, No. 1794 made in response to Case 61/81 E. C. Commission v. United Kingdom [1982] ECR 2601. As to U.K. sources generally, see Sweet \& Maxwell's Engyclopedia of European Community Law, Vols. A I and II (1973 and continued).

15.D. L. Keir and F. H. Lawson, Cases in Constitutional Law 6th ed. (1979), Preface, at p. v. 
constitutional changes. The starting point will be a consideration of what the Community expects of a new member and the British Government and Parliament's perception of and response to that expectation. From there, the reality of the relationship between Community law-making and Parliamentary sovereignty will be examined together with the role of Part I of the European Communities Act 1972. Finally an overall assessment will be attempted.

\section{The obligations of membership and the terms of British accession}

The procedure for the admission of a new member state under Article 237 of the EEC Treaty includes the Commission expressing an opinion on the application. The several opinions expressed by the Commission in connection with the sequence of applications made by the United Kingdom clearly spell out the basic terms of membership. In 1963 the Commission expressed the view that "any application for accession to the Community would mean that the country concerned unreservedly accepted the rules and objectives of the Treaty of Rome." 16 It was also made clear that the United Kingdom would have to accept not only the Treaty but also the substantial advances which had been made since the Treaty was signed ${ }^{17}$ and Community law would have to be given the same force in the United Kingdom as in the original member states. ${ }^{18}$ Four years later, at the time of the United Kingdom's second application, the Commission made an extensive study of the prospects for enlarging the Community. ${ }^{19}$ It referred to the scope of the obligations of new members in the following terms:

\footnotetext{
"Today, belonging to the Communities necessarily means accepting not only their original charters - the Treaties - but also the objectives of political unification affirmed in the Preambles to the Treaties ... Similarly, new members will have to accept the decisions taken since the Treaties were adopted. These decisions are the fruit of an often hard-won compromise between the Six, and they have also established an incontestable de facto solidarity between them. It would be impossible and illusory to attempt to call them into question. Consequently, as a general rule, a solution to the concrete problems will have to be sought by working out transitional measures and not by amending the existing rules." 20
}

In this Opinion the Commission took specific note of the differences between the United Kingdom legal system and the legal systems of the Six in the context of

16. EEC Commission, Report to the European Parliament on the state of the negotiations with the United Kingdom (1963), at p.12.

17. Ibid., at p.111.

18. Ibid., at p.104.

19. E. C. Commission, Opinion on the Applications for Membership received from the United Kingdom, Ireland, Denmark and Normay, COM (67) 750.

20. Ibid., at p.5.

21. Ibid., at p. 103 . 
the proper application of Community law in the United Kingdom. In the Commission's view, "The problems involved in establishing the conditions under which Community law will have its full effect in the United Kingdom do not in fact differ in character from those already encountered by the present Member States."21 The Commission was satisfied that the transfer to the Community, as required by the Treaty, of certain legislative powers "with the consequences this entails for the legislative activity of Parliament (adoption of measures required by Community law, present and future; avoidance of measures incompatible with Community law)" could be validly effected by Act of Parliament. ${ }^{22}$

The negotiations which led to membership proceeded on that basis so that in its favourable formal opinion on the eve of the signature of the Treaty of Accession the Commission was able to declare: (i) that the Treaties, their political objectives and all existing acts of the Community institutions were accepted without reserve; (ii) that essential features of the Community legal system were the direct applicability of Community law and its precedence over national provisions conflicting with it; and (iii) that accession entailed recognition of the binding force of those rules and of the indispensable nature of their observance as a guarantee of the effectiveness and unity of Community law. ${ }^{23}$ Therefore, by the Treaty and Act of Accession 1972, "the provisions of the original Treaties and the acts adopted by the institutions of the Communities" became binding on and applied in the United Kingdom from 1 January 1973 subject only to the transitional arrangements. ${ }^{24}$

It is very clear from government statements, Parliamentary Debates and other sources that the nature of the legal obligations of membership and their constitutional significance for the United Kingdom were fully appreciated. In two of the Commission Opinions cited earlier reference is made to specific undertakings by Her Majesty's Government to "subscribe fully to the various aims which the Governments of the member countries of the Community had set themselves", 25 to accept not only the economic but also the political objectives of the Treaties, ${ }^{26}$ and to accept "an unprecedented innovation in United Kingdom constitutional law" namely the "subordination of municipal law to Community law which is directly enforceable". ${ }^{27}$ As early as 1962 the then Lord Chancellor, Lord Dilhorne, in a debate on Britain and the Common Market said: "If one subscribes to the objectives of the Treaties it follows that one cannot logically object to the degree of supra-national determination and administration necessary to secure the

\section{Ibid}

23. E. C. Commission, Opinion of 19 Januay 1972 on Applications for Accession to the European Communities by Denmark, Ireland, Normay and the United Kingdom, JO 1972, L73/3.

24. Act of Accession 1972, art. 2.

25. Supra n. 16, at pp. 13-14.

26. Supra n. 19 , at p.18.

27. Ibid., at p.103. The recent assertion by Lord Denning that upon accession the aims of the Community were merely economic but have subsequently become political and legal is, with respect, unfounded; see House of Lords Debates, 5 th Series, 1985-86, Vol.479, col.1055 et seq. 
uniform application of policy throughout the member states to attain these objectives ... By agreeing to be bound by the Treaty we, of course, commit ourselves to comply with the provisions of that treaty."28 Five years later, under a different Government, a White Paper was published which assessed the legal and constitutional implications of United Kingdom membership. ${ }^{29}$ In a debate on that document the new Lord Chancellor, Lord Gardiner, said: "we have made it clear that it would not be our intention to change the nature, spirit or workings of the Community any more than would inevitably result from the fact that the number of members had increased from the present figure." 30 Both Conservative and Labour governments were therefore ad idem on this fundamental issue and the negotiations which led to accession in 1973 proceeded on this agreed basis. ${ }^{31}$ Parliamentary approval of the decision of principle to join the Community was also secured on that basis. ${ }^{32}$

Final confirmation of this, it is submitted, was given by means of the referendum on United Kingdom membership in 1975. The "renegotiations" which led up to the referendum were largely focussed on such specific issues as changes in the Common Agricultural Policy and the methods of financing the Community budget. $^{33}$ But one objective of the "renegotiations" potentially struck at the fundamental principles of Community law, namely the retention by the United Kingdom Parliament "of those powers over the British economy needed to pursue effective regional, industrial and fiscal policies" ${ }^{34}$ Further, the right was reserved "to propose changes in the Treaties if it should turn out that essential interests cannot be met without them." ${ }^{35}$ The referendum was therefore seen as addressing itself to a unique issue which had "fundamental implications for the future of this country, for the political relationship between the United Kingdom and the other Member Governments of the Community, and for the constitutional position of Parliament." 36 In the event the "renegotiations" turned out to be a classic instance of parturiunt montes nascitur ridiculus mus. On its own admission the Labour government did not achieve all its objectives in full. ${ }^{37}$ The Treaties remained

\section{House of Lords Debates, 5th Series, 1961-62, Vol.243, col.421.}

29. Legal and Constitutional Implications of United Kingdom Membership of the European Communities (1967), Cmnd.3301.

30. House of Lords Debates, 5th Series, 1966-67, Vol.282, col.1205.

31. For example, Mr Geoffrey Rippon in the second reading debate on the European Communities Bill relied on the 1967 White Paper and on the statements of Lord Gardiner: House of Commons Debates, 5th Series, 1971-72, Vol.831, cols. 278, 279. Similarly the Conservative Government in 1971 confirmed and adopted the negotiating stance which its predecessor had taken: The United Kingdom and the European Communities (1971), Cmnd.4715, para.22.

32. For the debate on the issue of principle, see House of Commons Debates, 5th Series, 1970-71, Vol.823 at cols. 911, 1094, 1234, 1480, 1731 and 2076.

33. See Renegotiation of the Terms of Entry into the European Economic Community (1974), Cmnd.5593. 34. Ibid., para.3, at p.4.

35. Ibid., para.15.

36. Referendum on United Kingdom Membership of the European Community (1975), Cmnd.5925, Preface, at p.2.

37. Membership of the European Community (1975), Cmnd.5999, at p.9. 
unamended. ${ }^{38}$ In relation to the specific areas of Parliamentary lawmaking raised in the "renegotiations", the government appears to have been satisfied that any problems could be solved by administrative means. ${ }^{39}$ On the more general and fundamental issue of the role of Parliament and its relationship with Community law the government did little more than re-iterate what had already been said in the 1967 White Paper: "National courts are required to apply directly applicable Community law and to give it priority should it conflict with national legislation." 40 Therefore the significance of the "renegotiations" as far as the fundamental legal obligations of membership were concerned was to confirm them. That confirmation was then included in the terms of the Government's recommendation to the electorate to vote for staying in the Community. ${ }^{41}$ The explanatory booklet which the Government circulated to all households prior to the referendum referred to the practical restraints on national freedom of action in the modern world and then said: "It is the Council of Ministers, and not the Market's officials, who take the important decisions. These decisions can be taken only if all the members of the Council agree. The Minister representing Britain can veto any proposal for a new law or a new tax if he considers it to be against British interests. Ministers from the other Governments have the same right to veto." ${ }^{\prime 2}$ The clear implication of this is that in all cases where the veto is not invoked the decision will be accepted by the British Government and implemented. The referendum was seen by the British Government as a unique event and as "the means by which the British people will decide the issue of our membership of the European community." 43 The clear-cut vote in favour of continuing membership may therefore be said to have signified popular approval of the terms of membership.

Once the "momentous decision" to join the European Communities had been made the way forward was very clear. As Lord Diplock put it in the House of Lords' debate on the European Communities Bill: "That decision having been made, the obligations which we thereby undertake under the Treaties make it inevitable what we have to do to comply with them. The constitutional and legislative system of this country makes it inevitable how, within comparatively narrow limits, we have to do it, and this Bill does no more than give legal effect to that political decision." 44 To some extent, as Lord Diplock's observation implies,

38. Although the government reserved the right to propose treaty revision in future if necessary, ibid., at p.8.

39. Ibid., at p.7 and Membership of the European Community: Report on Renegotiation (1975), Cmnd.6003, paras.52-68.

40. Cmnd.6003, para.133; the 1967 White Paper is quoted at length in para.134.

41. Ibid., paras.114-141.

42. Britain's New Deal in Europe, (HMSO, 1975) at p.12.

43. Statement by the Prime Minister on January 23, 1975, Supra n.36, Annex A, at p.10. Also see G. Winterton, "The British Grundnorm: Parliamentary Supremacy Re-examined", (1976) 92 L.Q.R. 591 and A. W. Bradley, "The Sovereignty of Parliament - in Perpetuity?", in J. Jowell and D. Oliver (Eds.), The Changing Constitution (1985) 23, at p.40.

44. House of Lords Debates, 5th Series, 1972, Vol.333, col.1275. 
the British Government and Parliament were faced with a not unfamiliar objective, namely that of giving domestic effect to the provisions of Treaties to which the United Kingdom had become a party. Legislation for this purpose is necessary because of the long-standing constitutional principle that "adherence to a treaty does not of itself have the effect of changing our internal law even where provisions of the treaty are intended to have direct internal effect as law within the participating States." 45 The "constitutional innovation", 46 however, lay in accepting future Community law as enforceable in the United Kingdom, enabling Community law to override national law so far as inconsistent with it, and requiring the courts of the United Kingdom to seek and accept the rulings of the European Court. ${ }^{47}$ The aim of Part I of the European Communities Act 1972 is to achieve all of those crucial objectives.

It is very clear from that Act and from official and unofficial statements made about it that those responsible for its preparation fully accepted the traditional view of parliamentary sovereignty. ${ }^{48}$ As Lord Dilhorne, L.C. put it in a debate in 1962: "An Act of Parliament would be required to apply these Treaties ... That Act of Parliament, like any other, could be repealed by a subsequent Act; and if that happened the Treaties would cease to be law in this country ... Parliament could repeal the Act applying these Treaties; it cannot be prevented from doing so."49 This traditional approach therefore relies upon the doctrine of parliamentary restraint to ensure that future laws made by Parliament are at all times compatible with Community law. Lord Dilhorne, earlier in the speech cited above, said: "In any subsequent legislation of our own we should have to take good care that it did not conflict with any Community regulations or directives." 50 This theme of restraint is taken up by the 1967 White Paper, ${ }^{51}$ by Lord Gardiner, L.C. ${ }^{52}$ and by $\mathrm{Mr}$ Geoffrey Rippon when he was introducing the European Communities Bill in the House of Commons. ${ }^{53}$ Again, as was pointed out at the time, ${ }^{54}$ as a matter of principle the doctrine of parliamentary restraint was not unprecedented, ${ }^{55}$ although here its scope and its significance for domestic law were both clearly

45. Legal and Constitutional Implications of United Kingdom Membership of the European Communities (1967), Cmnd.3301, para.22. Also see McWhirter v. Attomey General [1972] C.M.L.R. 882, per Lord Denning, M.R., at p.886.

46. Cmnd.3301, para.22.

47. Ibid., paras. 22,23 and 28.

48. See Sir Geoffrey Howe, "The European Communities Act 1972", (1973) International Affairs 1, at p.8.

49. House of Lords Debates, 5th Series, 1961-62, Vol.243, cols.421-422. Also see the Foreign Secretary (Earl of Home) to the same effect, ibid., col.279.

50. Ibid., col.420.

51. Cmnd.3301, para.23.

52. House of Lords Debates, 5th Series, 1966-67, Vol.282, col.1202.

53. House of Commons Debales, 5th Series, 1971-72, Vol.831, col.279.

54. See nn.51 and 52, supra.

55. For example, restraint in relation to legislation in conflict with the Statute of Westminster, 1931 and as a result of treaty constraints imposed by membership of GATT, NATO, and the UN. 
novel. Successive British Governments in contemplating the practicalities of honouring the obligations of membership of the European Community therefore proceeded on the basis that proper restraint would be exercised by Parliament. In terms of Lord Dilhorne's striking simile: "Just as a person does not contemplate divorce when embarking on matrimony ... so here, if we decide to join, we must, I submit, do it wholeheartedly and with the intention of playing our full part as a member of the Community in fostering its purposes and objectives." apparent risk to the unity and uniformity of Community law represented by the continued existence of the "ultimate sovereignty of Parliament" practice be removed by the political fact of British membership. Thus true to British constitutional tradition and practice a wholly conventional and pragmatic means of achieving the supremacy of Community law was adopted, supported by a statutory injunction to the courts in favour of Community law. ${ }^{58} \mathrm{Sir}$ Geoffrey Howe, speaking on behalf of himself and his ministerial colleagues, said at the time: "We did not believe that we could have done more than this to resolve, in advance, every problem or possible conflict that might perhaps arise in the future." 59

It has already been pointed out that the Commission of the European Communities was fully satisfied that the United Kingdom would be able to honour the obligations of membership by the political and legal means proposed, despite the retention of the ultimate sovereignty of Parliament. ${ }^{60}$ It is indeed arguable that the doctrine of parliamentary restraint is entirely compatible with Article 5 of the EEC Treaty which requires member states to "abstain from any measure which could jeopardise the attainment of the objectives of this Treaty" ${ }^{\prime 61}$ and does not in terms call for a legal guarantee of such abstention.

It was not doubted that acceptance of membership of the European Community on the terms negotiated would have far-reaching consequences for the practical exercise of law-making power by Parliament. This was fully appreciated, for example, by the Royal Commission on the Constitution the deliberations of which took place against the background of the accession negotiations. ${ }^{62}$ All members of the Royal Commission accepted the traditional doctine of the supremacy of Parliament, ${ }^{63}$ but it was acknowledged that British membership of the European Community would involve "the acceptance of a measure of government from

56. House of Lords Debates, 5th Series, 1961-62, Vol.243, col.422.

57. A term used by Mr Geoffrey Rippon: see House of Commons Debates, 5th Series, 1971-72, Vol.831, col.278.

58. By virtue of European Communities Act 1972, s.2(4) to be discussed further below. On the aim of that subsection see supra $\mathrm{n} .57$ and Lord Hailsham, L.C. in House of Lords Debates, 5th Series, 1972, Vol. 333, col.1230.

59. "The European Communities Act 1972", (1973) 49 Intemational Affairs 1, at p.10.

60. Supra n.21.

61. Emphasis added.

62. The Royal Commission began its work in 1969 and reported in October 1973.

63. See the Royal Commission's Report, Vol.1, Cmnd.5460, para.56. 
Brussels". ${ }^{64}$ Therefore, in the context of the Royal Commission's consideration of devolution, a practical consequence of membership would be that "The powers that might be devolved and the freedom with which those powers could be exercised by the regions would be restricted by Community provisions applicable within the United Kingdom." 65 The dissenting minority on the Royal Commission agreed with this and said that "it would hardly make sense ... to seek to devolve legislative power and sovereignty ... in those matters where legislative authority is in fact moving from London to Brussels." ${ }^{66}$ As Mr Enoch Powell, a well-known opponent of British membership, put it recently "In 1972 the House made a comprehensive renunciation of its powers - legislative and financial - and of British judicial authority and of the control of the House over policy. It did that on the basis of the treaty to which we were acceding ..."67

\section{Community law, Parliament and the European Communities Act}

The assertion was made at the outset that during the fourteen years of membership the United Kingdom has been a full and loyal participant in the new constitutional and legal order which it has entered. Despite what Lord Bridge has suggested is an "inherent weakness of our constitution" 68 the forecast of a pair of early commentators has proved accurate and we have "found enough constitutional space to ensure the supremacy of directly applicable Community law ..."69 Most attempts to analyse how this has happened have tended to focus on Part I of the European Communities Act and the role of the judges. This is understandable because those matters have a high visibility and are overt manifestations of the actuality of British membership. Whilst it is not intended to deny the important part played by the Act and by our judges, it is submitted that there are less public but more fundamental factors which explain and in a real sense guarantee our fulfilment of the conditions of membership. These involve the nature of Community law and the part played by the United Kingdom Government in law-making both by the Community and by Parliament.

In the first place, a characteristic feature of Community law as a new and independent legal order with the goal of achieving economic integration is that in a number of important fields it replaces the domestic laws of the member states. ${ }^{70}$ To take two major instances, both the rules of customs law and of the law relating

64. Ibid., para.409.

65. Ibid., para. 404 . Also see para. 413 to the same effect.

66. See the "Memorandum of Dissent by Lord Crowther-Hunt and Professor A. T. Peacock", Royal Commission's Report, Vol.2, Cmnd.5460-I, para.83. Also see paras.86 and 88 to the same effect.

67. In a debate on the European Community and the Single European Act, House of Commons Debates, 6th Series, 1985-86, Vol.93, cols.352-353. As to the Single European Act, see European Communities No.12 (1986), Cmnd.9758.

68. Supra n.11, at p.117.

69. G. Child and J. Evans, Britain, Europe and the Law (1973), at p.20.

70. See generally J. Usher, European Community Lam and National Law (1981), Ch.3. 
to agriculture currently in force in the United Kingdom are the relevant rules of Community law. The Commissioners of Customs and Excise and the Intervention Board for Agricultural Produce respectively are performing Community functions in pursuance of directly applicable Community regulations. ${ }^{71}$ As the European Court has said in relation to customs law: "the Common Customs Tariff [has] replaced the national customs tariff of the Member States and, subject to review by the courts responsible for applying and interpreting Community law, in particular on questions raised under Article 177 of the Treaty, the Community authorities alone have jurisdiction to interpret and determine the legal effect of the headings which it comprises." 72 A recent case provides a clear illustration of the practical effect of this ruling in the United Kingdom. H.M. Customs seized consignments of inflatable, life-size "sex dolls", which were being imported into the United Kingdom from the Federal Republic of Germany, on the grounds that the seizure was justified by the public morality exception in the rules of Community law concerning the free movement of goods. ${ }^{73}$ The seizure was challenged in an English court which sought a preliminary ruling on the point from the European Court. That Court ruled that the public morality exception did not apply to these goods since they were not prohibited from manufacture or sale within the United Kingdom. The seizure was therefore an unjustified restriction on imports contrary to Article 30 of the EEC Treaty. ${ }^{74}$ The outcome of this case was subsequently challenged in questions asked in the House of Lords. ${ }^{75}$ Lord Denning criticised the European Court's ruling and asked: "are we not entitled to go by the Treaty of Rome itself and to ignore, if you please, the wrong decisions of the European Court, or can we not tell our courts to cock a snook at the European court?" ${ }^{\prime 76}$ But the Government's spokesman made it clear that no such option was in fact open: "under the Treaty of Rome the government are bound by the judgment of the European Court of Justice. Henceforth Customs and Excise will apply their controls on imported goods in line with the court's judgment." applicability of the relevant rules of law and the acknowledgement of the binding nature of the European Court's interpretation of them, the Government, as the manager and initiator of Parliament's legislative business, is clearly not going to introduce bills relating to customs matters. The field has been pre-empted by Community law. While Parliament, as a matter of law, retains the authority to

71. See Halsbury's Laws of England 4th ed., vol.51, European Communities, Title 3: Application of Community Law in National Courts, paras.3.28, 3.29.

72. Case 38/75 Dowaneagent der N.V. Nederlandse Spoonwegen v. Inspecteur der invoerrechten en acginzen [1975] E.C.R. 1439, at p.1449. For cases to similar effect in relation to agriculture see J. Usher, supra n.70.

73. See EEC Treaty, art.36.

74. Case 121/85 Conegate Lid v. H.M. Customs and Excise [1986] 1 C.M.L.R. 739.

75. House of Lords Debates, 5th Series, 1985-86, Vol.475, col.702.

76. Ibid., col.703. Also see Lord Denning's comments in House of Lords Debates, 5th Series, 1985-86, Vol.479, cols.1057-1058.

77. Supra n.75, col. 702, per the Secretary of State for Employment (Lord Young of Graffham). 
legislate in that field, as a practical matter the opportunity to do so will not arise. In such situations as these there can be no real risk of our domestic law conflicting with Community law because Community law occupies the field.

Secondly, while the substantive content of Community rules is a matter of Community law, whenever those rules are changed or new ones made the participation by the United Kingdom in the Community's law-making processes is of supreme constitutional significance. It must be remembered that the Council is the principal Community legislator both in the sense of law-making in its own name and in the sense of having authority to confer law-making powers on the Commission. ${ }^{78}$ As a member of the Council the United Kingdom Government therefore participates in all exercises of this legislative authority. Under the terms of the EEC Treaty two patterns of voting are employed in the Council: a qualified majority as defined in Article 148 (2), as amended; and unanimity. Unanimity is required most notably for the issuing of directives by the Council under Article 100 for the purpose of the approximation of laws. In such a case each member state in effect has a veto. If a directive is issued then, by definition, each member state will have voted in favour of it. Such a vote by the United Kingdom Government implies that the government is willing and intends to take the necessary implementing measures by introducing legislation or otherwise, as appropriate. The practical effect of this is to limit significantly the scope for Parliamentary legislation in the field covered by the directive since it may reasonably be supposed that any legislation proposed by the Government in this connection will be tailor-made to serve the objectives of the directive to which agreement has already been given. As the House of Lords Select Committee on the European Communities has put it: "In concrete terms, the issue by the Council of a directive under Article 100 takes out of the democratic process of the United Kingdom's Parliament a part of that country's legislative activity. Moreover, since a directive once adopted can be repealed only with the agreement of all the Member States, the result of the directive is to move to the Council part of the country's legislative activity with no practical possibility of getting it back.",79

As far as regulations are concerned the general voting requirement is a qualified majority, ${ }^{80}$ subject to the availability of an extra-legal power of veto under the terms of the Luxembourg Accords of $1966^{81}$ whenever "very important interests" of one or more member states are at stake. Again, a range of practical possibilities present themselves. If the United Kingdom Government forms part of a qualified majority in favour of a regulation, or if it opposes a regulation and is out-voted and does not invoke the Luxembourg Accords, then a regulation will be made. Such a

78. See D. Lasok and J. W. Bridge, supra n.3., Chs. 5, 6 and 8(D).

79. Session 1977-78, 22nd Report, Approximation of Lams under article 100 of the EEC Treaty, para. 15. 80. See EEC Treaty, art.148(2), as amended.

81. See EEC Bulletin, 1966, No.3, at pp.9, 10. Also see D. Lasok and J. W. Bridge, supra n.3, at pp.181-185. 
regulation, as a directly applicable act ${ }^{82}$ and by virtue of section 2 (1) of the European Communities Act 1972, will without further enactment be recognised and available in law, and be enforced, allowed and followed in the United Kingdom. In such a situation any conflict with prior United Kingdom law will be resolved in favour of the regulation by the simple operation of the lex posterior rule. Since in such a case the United Kingdom Government will have taken part in the preparation and enactment of the regulation and will have either voted in favour of it or at least acquiesced in it, the likelihood of the Government introducing incompatible legislative proposals in Parliament is extremely remote. ${ }^{83}$ If, on the other hand, the United Kingdom Government invokes the Luxembourg Accords and uses the veto, then no regulation will be made until the Government is satisfied that our "very important interests" have been safeguarded and until then there can be no possibility of conflict with our domestic law on that particular issue. Although under the terms of the Single European Act, ${ }^{84}$ for the purposes of completing the Community's internal market, there will be a move from unanimity to qualified majority voting it has been made clear that the Luxembourg Accords remain in place and unaffected. ${ }^{85}$

Successive British Governments have taken very seriously the responsibilty, in effect remitted to them by Parliament through passing the European Communities Act 1972, for safeguarding United Kingdom interests in the deliberations of the Council which result in directly applicable Community law. ${ }^{86}$ This has not always endeared the United Kingdom to the other member states: "Although the United Kingdom faithfully implements decisions once they have been taken, other Member States see it as reluctant to allow the decisions to be taken in the first place and insisting on every detail being explored and settled in advance." ${ }^{87}$ While in a sense this may make the United Kingdom seem less extrovertly communautaire than some members, in terms of commitment to Community law once the decisions have been taken the United Kingdom may in some respects be said to be more communautaire than some. This need to be fully convinced before a decision is taken also makes it highly unlikely that any contradictory national legislation will in practice be introduced in Parliament.

For the practical reasons rehearsed above it is submitted that United Kingdom legislation expressly opposing the requirements of Community law is extremely

82. By virtue of EEC Treaty, art.189.

83. Cf. Lord Gardiner, L.C., House of Lords Debates, 5th Series, 1966-67, Vol.282, col.1203.

84. See European Communities No. 12 (1986) Cmnd.9758, in particular arts.13-19.

85. See the Statement by the Foreign Secretary (Sir Geoffrey Howe), House of Commons Debates, 6th Series, 1985-86, Vol.96, cols.319-321. For a less sanguine view see House of Lords Select Committee on the European Communities, Session 1985-86, 12th Report, The Single European Act and Parliamentany Sorutiny, paras.14 \& 15.

86. Cf. Membership of the European Community: Report on Renegotiation (1975), Cmnd.6003, para.136 and House of Lords Select Committee on the European Communities, Session 1984-85, 14th Report, European Union, para.46.

87. House of Lords Report on European Union, ibid., para.27. 
unlikely given the political fact of continuing British membership: "it is unlikely that Parliament in these circumstances would wish to proceed with matters inconsistent with treaty obligations." 88 A working assumption can therefore be advanced that at any given time the Community rules, in the making of which the United Kingdom has participated, will fill the occupied field of Community concern and that United Kingdom legislation, apart from where it is designed to achieve some Community goal, will concern itself with the remaining unoccupied field. The United Kingdom Government is effectively in control of the legislative programme of the British Parliament and is also a Community legislator through its membership of the Council. The Government is therefore well-placed to maintain compatibility between the two legal orders. The effectiveness of Part I of the European Communities Act 1972 and the nature of the demands placed on the judiciary by our Community membership must therefore be considered against this background of political reality; ${ }^{89}$ consideration in the light of abstract law while intellectually challenging will not, given the nature of our constitution, tell us much about how the system works in practice. Any discrepancies between Community law and laws made by the British Parliament are therefore likely to be unintentional and the result of inadvertence or faulty drafting. Therefore the combination of the statutory rule of construction in favour of Community law ${ }^{90}$ and the requirement that our judges interpret and apply Community law in accordance with the case law of the European Court ${ }^{91}$ provide perfectly adequate practical means of correcting such discrepancies. As Sir Geoffrey Howe has put it:

"What the Act seeks to do ... is to enjoin our courts, in their interpretation of future legislation, to give full effect to the concept of 'enforceable Community rights' which, as defined in section 2 (1) (and the treaties), contains the element of supremacy ... All, therefore, that our courts have been required to do is simply to limit the consequences of any United Kingdom statute that does conflict with Community law, though in the case of a future statute any limitation of its consequences would be confined to what is practicable and would not be likely to iron out a conflict which was plainly intentional.",92

This expectation, faciliated by the consistent exercise of parliamentary restraint, has been realised in the form of Lord Denning's landmark judgment in Macarthy's $L t d$. v. Smith, in which he advanced the principle of construction that the courts should always presume that Parliament intended to legislate in conformity with our obligations as a member of the Community unless the contrary is stated in express

88. Mr Geoffrey Rippon, House of Commons Debates, 5th Series, 1971-72, Vol.831, col.279.

89. As J. D. B. Mitchell once observed "constitutional law is, at least, a half-brother to politics": supra n.4, at p.73.

90. See European Communities Act 1972, s.2(4).

91. Ibid., s.3(1).

92. Supra n.48, at pp.7 and 10 . 
terms. ${ }^{93}$ This principle has subsequently received a measure of support from the House of Lords. ${ }^{94}$

The assertion that the European Communities Act 1972 can only be amended or repealed by intentional and express terms in a subsequent Act raises questions concerning the doctrine of implied repeal. That doctrine, which is seen as a corollary to the traditional doctrine of the sovereignty of Parliament, takes the lex posterior rule to its logical extreme and provides that "when two Acts conflict the later is construed as amending or repealing the earlier one." $" 95$ If a directly applicable rule of Community law, which is enforceable in the United Kingdom by virtue of section 2 (1) of the European Communities Act 1972, says X and an Act of the United Kingdom Parliament of a later date says X minus 1, has that later Act impliedly repealed either the European Communities Act pro tanto or the Community rule in question? It is submitted that the answer to that question is "no" and that that answer has much more to do with the scope of the doctrine of implied repeal and the relationship between Community law and the European Communities Act than it has with the doctrine of the supremacy of Community law. The fallacy inherent in the view that the doctrine of implied repeal applies in situations like the hypothetical one mentioned above ${ }^{96}$ has already been exposed by Evelyn Ellis: "implied repeal occurs where, as in the Vauxhall and Ellen Street cases, statute 1 makes provision for a particular situation and then statute 2 is passed saying something different about that same situation. There is thus an inconsistency between the two Acts and, to the extent of this inconsistency, statute 2 prevails over and impliedly repeals statute 1 . In the Macarthys type situation there is a conflict between Community law and an English statute, but there is no conflict between the European Communities Act and any other piece of legislation; the only inconsistency is as between the Community law on sex discrimination and the English statute. Accordingly, there is no question of the repeal of the European Communities Act either impliedly or otherwise." 97 An important contributing factor to this outcome is of course the generality of the terms of sections 2 and 3 of the European Communities Act. Those provisions reflect both the separate nature of the rules of Community law and their continuing significance for the English legal system. But, in addition, their generality distances the actual rules of

93. [1979] 3 C.M.L.R. 44, at pp.46-47. Lord Denning re-iterated this principle in his What Next in the Law (1982, at pp.296-300. Also see T. R. S. Allan, supra n.13.

94. See Garland v. British Rail Engineering Lid. [1983] 2 A.C. 751, per Lord Diplock (giving the unanimous judgment of the House), at p.771. Also see O. Hood Phillips, "A Garland for the Lords: Parliament and Community Law Again", (1982) 98 L.Q.R. 524 and T. R. S. Allan, "Parliamentary Sovereignty and the EEC", [1982] Public Law 562.

95. Per Lord Hailsham, L.C., House of Lords Debates, 5th Series, 1972, Vol. 333, col.1230.

96. See O. Hood Phillips, "Has the incoming tide reached the Palace of Westminster?", (1979) 95 L.Q.R. 167 and "High Tide in the Strand? Post 1972 Acts and Community Law", (1980) 96 L.Q.R. 31. 97. "Supremacy of Parliament and European L.aw", (1980) 96 L.Q.R. 511, at p.513. The cases cited in the passage quoted are Vauxhall Estates Lid. v. Liverpool Corporation [1932] 1 K.B. 733, Ellen Street Estates Ltd. v. Minister of Health [1934] 1 K.B. 590, and Macarthys Lid v. Smith, supra n.93. 
Community law from the rules of United Kingdom law thus avoiding a direct confrontation between them and making implied repeal in the situation described above impossible.

But is the implied repeal of the European Communities Act impossible in all situations? Clearly there is no obstacle to its implied repeal in a situation in which there is an inconsistency between that Act and a later Act. ${ }^{98}$ In this connection it is interesting to consider whether section 1 (3) of the European Communities Act has been impliedly amended by section 6 of the European Assembly Elections Act 1978. Section 1 (3) of the 1972 Act lays down a procedure whereby Her Majesty in Council may specify a treaty to be a Community treaty for the purposes of the European Communities Act subject only to the Order in Council being approved by both Houses of Parliament. Various additional treaties have been so specified from time to time, for example the Financial Provisions Treaty of 1975 which amended the Community's budgetary arrangements. ${ }^{99}$ Implicit in this procedure is the rule that the making of treaties is an executive act in which Parliament plays no role. ${ }^{1}$ Section 6 of the 1978 Act introduces a constitutional novelty by stating that no treaty which provides for any increase in the powers of the Assembly shall be ratified by the United Kingdom unless it has been approved by an Act of Parliament. That provision is clearly designed to limit the Crown's power of treaty-making in an area of particular concern to the Community. It requires in respect of a particular type of treaty prior statutory approval rather than approval by parliamentary resolution after the treaty has been concluded. Thus there are here two Acts which say different things about the same situation and in accordance with the doctrine of implied repeal it must be presumed that the latter Act prevails as a matter of United Kingdom law. It does not necessarily follow that such constitutional change will impede the United Kingdom's acceptance and implementation of any future treaty which may confer additional powers on the European Parliament. Any such treaty would require the unanimous approval of the member states. ${ }^{2}$ Where such a treaty is in fact made then presumably the United Kingdom Government of the day would secure the passing of the required Act of Parliament. ${ }^{3}$ That has in fact just happened for the first time. Two of the provisions of the Single European Act 1986 amend the EEC Treaty to give the European Parliament the right to assent to the future accession of new members and associate members. ${ }^{4}$ We therefore find in the European Communities

98. See Evelyn Ellis, ibid., at p.514.

99. See European Communities (Definition of Treaties) Order 1976, S.I. 1976, No.217.

1. See Blackbum v. Allomey General [1971] 1 W.L.R. 1037, per Lord Denning, M.R., at p.1040.

2. Under the terms of EEC Treaty, art.236.

3. If such an Act was not passed then the United Kingdom would clearly have committed a breach of EEC Treaty, art. 5 by failing to take all appropriate measures to ensure fulfilment of Community obligations. For a case in point see Case 128/78 EC Commission v. United Kingdom [1979] E.C.R. 419 (the tachograph case).

4. Arts. 8 and 9 which amend EEC Treaty, arts. 237 and 238 respectively; see European Communities No. 12 (1986), Cmnd.9758. 
(Amendment) Act 1986, the principal aim of which is to amend the European Communities Act 1972 in the light of the Single European Act, ${ }^{5}$ a section which provides: "For the purpose of section 6 of the European Assembly Elections Act 1978 the Single European Act is hereby approved."

The House of Lords in Garland did not expressly rule out the possibility of the implied repeal of a rule of Community law by a later British statute. But it is suggested that, by giving broad support for Lord Denning's constructionist approach and given the likely nature of actual inconsistences between British statutes and rules of Community law, judicial decisions resolving such inconsistencies in favour of Community law are effectively guaranteed.

\section{Conclusion}

It is clear that since 1 January 1973 the United Kingdom has accepted and participated in a form of two-tier central government with an accompanying duality of legal orders. ${ }^{7}$ Policy-making and law-making are no longer the exclusive concern of the United Kingdom Government and Parliament; significant areas of policy-making and law-making have been transferred to the institutions of the Community, with the important rider that such policy and law takes precedence over conflicting national policy and law. In support of the political decision to accede to the Community our Parliament has, in effect, identified the area within which Community law will operate and within that area it has refrained from exercising its own law-making power other than as required by Community law. Clearly something very remarkable has happened but not, it is submitted, something which is entirely unprecedented.

One commentator has spoken of the process of joining the European Communities in the following terms: "Britain's accession to the European Communities was analogous to a constitutional amendment of an unprecedented kind, and the process followed for the decision to join was in itself a constitutional exercise. Wholly new processes might have been used, but instead the ordinary parliamentary legislative procedure was made to serve this unusual purpose."8 This is indeed no more than the history of constitutional change in this country would suggest: "it has always been convenient, if at all possible, to disguise change as continuity, even where continuity might be ambiguous." 9 This, in turn,

5. Excluding the provisions of the Single European Act which relate to co-operation in the sphere of foreign policy.

6. Section 3(4).

7. Cf. Report of the Royal Commission on the Constitution, Vol.1, Cmnd.5460, para.410 and W. Wallace, "Less than a Federation, More than a Regime: the Community as a Political System", in H. Wallace, W. Wallace and C. Webb (Eds.), Policy Making in the European Community 2nd. ed. (1983) 401, at pp.406, 410 .

8. P. Bromhead, Britain's Developing Constitution (1974), at p.213.

9. J. D. B. Mitchell, "The Sovereignty of Parliament and Community Law: The Stumbling Block That Isn't There", (1979) 55 International Affairs 33, at p.39. 
reflects the familiar dichotomy between continuing abstract constitutional legality and changing political constitutional reality. ${ }^{10}$ In terms of the former, Parliament retains its absolute power to legislate on any conceivable matter; in terms of the latter, Parliament's power is limited in accordance with "an established pattern of commitments", 11 the content of which is subject to change. The factors which, as has been argued above, ensure practical British compliance with the obligations of membership of the Community are the necessary products of the fact of a continuing and willing British membership. While legally nothing has changed, constitutionally, i.e. politically, there has been a major re-allocation of legislative power: "To this extent, and in the area occupied by Community law, parliamentary sovereignty may be said to be in abeyance." 12 Or, as Sir Leslie Scarman (as he then was) has put it, British membership of the Community has ended "in fact, if not in theory, Parliament's power on all occasions and whenever it chooses to legislate as it alone thinks fit." "Any future British legislation which was intentionally and expressly contrary to Community law or which repealed the European Communities Act would reflect not so much a re-assertion of the legal sovereignty of Parliament as an exercise of the political sovereignty of the government of the day and, consequently, a fundamental change in Britain's relationship with the Community.

A consideration of the constitutional impact of membership of the Community naturally prompts comparisons with the emancipation of the British Empire. The apparent distinction between the territorial extent of legislative authority on the one hand, and the scope of the subject matter of legislation on the other is one of no practical significance, given the continuing and absolute nature of the legal sovereignty of Parliament. Nor can the apparent efficacy of the legislative measures for the emancipation of the British Empire be taken to establish Parliament's capacity legally to limit its own powers. Such a conclusion is fallacious since it fails to give proper weight to the long-established and prevailing views, not least in Commonwealth countries themselves, of the extent of the legal powers of the British Parliament. Long after Lord Sankey's famous dictum in British Coal Corporation v. The King, ${ }^{14}$ the governments, parliaments and courts of Canada and Australia have fully acknowledged the continuing nature of the legislative supremacy of the British Parliament. In litigation arising out of the patriation of the Canadian constitution, for which purpose Canada requested and

10. This dichotomy is also reflected in the title of the 1967 White Paper, Legal and Constitutional Implications of United Kingdom Membership of the European Communities, Cmnd.3301. It has also received some judicial recognition: see Lord Denning's reference to "a constitutional point" in Macarthys Ltd.v. Smith [1979] 3 C.M.L.R. 44 at p. 47 and Sir Robert Megarry's express reservation in respect of the European Communities Act in Manuel v. Attomey General [1983] Ch.77, at p.86.

11. G. Watson, The British Constitution and Europe (1959), at p.65.

12. C. Turpin, British Government and the Constitulion (1985), at p.284.

13. "Law and Administration: A Change in Relationship" (1972) 50 Public Administration 253, at p. 255 .

14. [1935] A.C. 500, at p.520. 
consented to the passing of the Canada Act 1982 by the United Kingdom Parliament, the Supreme Court of Canada held that "The legal competence of [the British] Parliament ... remains unimpaired, and it is for it alone to determine if and how it will act."15 And, further, speaking of the Statute of Westminster, 1931: "whatever the Statute may import as to intra-Canadian conventional procedures, there is nothing in it or in the proceedings leading up to it that casts any doubt in law as to the undiminished authority of the Parliament of the United Kingdom over the British North America Act, 1867."16 The recent Australia Act $1986,{ }^{17}$ passed at the request and with the consent of Australia to achieve a similar purpose, also proceeded on the same basis and against the background of the acknowledgement by the High Court of Australia that "The United Kingdom Parliament could of course repeal the Statute of Westminster. It could repeal the Commonwealth of Australia Constitution Act." ${ }^{18}$ 'Therefore, the reason for the effectiveness of the emancipation of Canada and Australia lies not in any formal legal restraint on the British Parliament (for none is possible), but in the political reality of the relationship between the United Kingdom and those countries. ${ }^{19}$ That relationship is a constitutional relationship which is based on "the acceptance of a doctrine, almost amounting to a principle in itself, that the great self-governing Dominions are not any longer in tutelage but are constituent units of the British Commonwealth of Nations." 20 Just as, constitutionally, it is out of the question for the United Kingdom to legislate for Canada or Australia without its request and consent, so it is equally out of the question for the United Kingdom Parliament to invade the area occupied by Community law or otherwise legislate contrary to it. The nature of the constitutional relationship is different in each case but both involve the continuing exercise of political restraint on Parliament and in each case the end result is the same. To adopt the terminology of $\mathrm{Mr}$ Justice Rand of the Supreme Court of Canada, within the area occupied by Community law the

15. Reference Re Amendment of the Constitution of Canada (Nos I, 2 and 3) (1982) 125 D.L.R. (3d) 1, at p.41.

16. Ibid., at p.42, emphasis added. Also see Manuel v. Attomey-General [1983] Ch.77 (Megarry, V.C. and C.A.).

17. See I. S. Dickinson, "The Australia Act 1986 - An End to Constitutional Links between Australia and the UK", (1986) 136 New Lam foumal 401.

18. Bistric v. Rokov (1976) 135 C.L.R. 552, at p.567 per Murphy, J. By the same token it could also repeal the Canada Act 1982 and the Australia Act 1986.

19. It is of interest that in The Commonwealth v. Queensland Murphy, J. cites British membership of the European Community as one of the factors which confirms the independence and political separation of Australia from the United Kingdom; see (1975) 134 C.L.R. 298, at p.334.

20. The Commonmealih v. Kreglinger \& Femau Lid. (1926) 37 C.L.R. 393, at pp.413-414 per Isaacs, J. who also cites the report of the Imperial Conference of 1926 to similar effect. More recent opinions of the Judicial Committee in Ibralebbe v. The Queen [1964] A.C. 900, Bribery Commissioner v. Ranasinghe [1965] A.C. 172, and Akar v. Attomey-General of Sierra Leone [1970] A.C. 853 are not relevant in this context because they are concerned with the powers of the Parliaments of Ceylon and Sierra Leone and not with those of the United Kingdom Parliament. On this point see Cormack v. Cope (1974) 131 C.L.R. 432, at p.452 per Barwick, C. J.. 
United Kingdom Parliament has become a "bare legislative trustee" for the Community. ${ }^{21}$ Given continuing political commitment to the Community, the practical guarantee of our loyalty is at least as effective as in those member states which have a written constitution. ${ }^{22}$

By means of what Lord Watson, almost 100 years ago, aptly termed "the silent operation of constitutional principles" 23 there has once again occurred "a constitutional, not legal, abdication of sovereignty,"24, this time in favour of the European Community. Recent attempts to re-open this issue in the context of the acceptance and implementation of the Single European Act are quite misconceived. ${ }^{25}$ The crucial constitutional decision was taken in 1972, after very careful consideration, and confirmed in 1975. The Single European Act is no more than a logical progression of what was decided then. ${ }^{26}$ To vary Lord Denning's sea metaphor, very much more than our feet have become wet, we are rather in mid-channel and swimming strongly with the current.

21. I.C. Rand, "Some Aspects of Canadian Constitutionalism", (1960) 38 Canadian Bar Reviem 135, at $\mathrm{p} .145$.

22. Sed quaere whether we now have a form of written constitution subject to judicial review exercised by the European Court.

23. Cooper v. Stuart (1889) 14 App. Cas. 286, at p.293.

24. A. Berriedale Keith, The Dominions as Sovereign States (1938), at p.122.

25. See the parliamentary debates on the second reading of the European Communities (Amendment) Bill: House of Commons Debates, 6th Series, 1985-86, Vol.96, cols.316-393 and House of Lords Debates, 5th Series, 1985-86, Vol.479, cols. 1004-1034, 1046-1088. Also see letters to The Times on 6, 8, 12, 16, 19, 23, 26 and 28 May, 1986 and R. Scruton, "May the Lords preserve us", The Times, 23 September 1986, at p.12.

26. Cf. Lord Bethell, House of Lords Debates, 5th Series, 1985-86, Vol. 479, cols.1061-1062. 